\title{
ANTIBIOFILM POTENCY OF GINGER (ZINGIBER OFFICINALE) AND QUERCETIN AGAINST STAPHYLOCOCCUS AUREUS ISOLATED FROM URINARY TRACT CATHETERIZED PATIENTS
}

\author{
HAMASALIH, R. M. ${ }^{*}$ - ABDULRAHMAN, Z. F. A. \\ Department of Biology, Salahaddin University-Erbil, Erbil, Iraq \\ *Corresponding author \\ e-mail: rebwar.hamasalih@su.edu.krd; phone: +964-751-268-6561 \\ (Received 28 $8^{\text {th }}$ Jul 2019; accepted $28^{\text {th }}$ Nov 2019)
}

\begin{abstract}
Staphylococcus aureus is a common cause of urinary tract infections associated with catheters. Biofilm is a community of microbial cells attached to a surface and is embedded in the extracellular polymeric substances. Catheters were collected from 157 patients; S. aureus was identified by molecular and conventional microbiological methods. S. aureus isolates showed a higher level of biofilm production, and all isolates showed biofilm production using Microtiter plate assay, while $89 \%$ of the isolates produced using Congo red agar method. All biofilm-producing isolates were positive for icaC, icaD, and cna genes, except isolate SA88, indicating the vital role of ica genes as markers of virulence in S. aureus infections. The difference in the inhibition of biofilm formation between the culture containing $Z$. officinale extract and the control was recorded. The high percentage of biofilm inhibition was 61.4 against SA04 at a concentration of $16 \%$, whereas there is no effect on the formation of biofilm at concentrations $4,2,1$, and $0.5 \%$ against each of SA36, SA48, and SA62. Quercetin lowers the formation of biofilm against SA36 of S. aureus at $32 \mu \mathrm{g} / \mathrm{mL}$ compared to a positive control $(p=0.0041)$, and the percentage of inhibition power reached to 92 . At a concentration $32 \mu \mathrm{g} / \mathrm{mL}$, the highest antibiofilm potential of ascorbic acid was 62 percent against SA86 strain, while at a concentration of $4 \mu \mathrm{g} / \mathrm{mL}$, the minimum potency was recorded toward SA62 isolate.
\end{abstract}

Keywords: bacterial isolates, catheters, biofilm-related genes, PCR

\section{Introduction}

Staphylococcus aureus is responsible for causing a variety of human-acquired community and hospital-acquired infections worldwide. A significant number of $S$. aureus clinical isolates have evolved to be resistant to commonly used antibiotics (Jeong et al., 2019). The importance of nosocomial diseases caused by S. aureus, especially by methicillin resistant $S$. aureus (MRSA), is well known for its frequency, morbidity, mortality, and principally for its difficulty to treat (Shin et al., 2010; Saraiva et al., 2012). Resistance has also been reported against both newly introduced and lastresort drugs such as vancomycin, daptomycin, and linezolid used for the treatment of $S$. aureus infection. Therefore, new therapies against this series human pathogens need to be developed urgently (Nair et al., 2016). S. aureus, including antibiotic-resistant strains, are highly biofilm-producing bacteria and are dangerous causes of common infectious diseases in humans (Phuong et al., 2017; Wang et al., 2017). Due to genetic and metabolic adaptations of cells in films, the bacteria in biofilms are highly tolerant to antimicrobials. Biofilms consist of both the cells and the extracellular matrix produced by the cells (Shahmoradi et al., 2019), bacterial cell communities in a self-produced polymer matrix, and adhere to an inert or living surface (Onsare and Arora, 2015; Singh et al., 2015).

$S$. aureus is known to form biofilms, and it has been shown that reside in biofilms are highly resistant to antibiotics (Rodrigues et al., 2017), and also is a leading cause of skin 
structure infections and it is particularly associated with urinary tract catheters (Bayer et al., 2016; Trübe et al., 2019). S. aureus produces several virulence factors that enable it to colonize, adhere to surfaces and form biofilms, invade or escape the immune system, develop resistance to multiple antibiotics and cause host toxicity (Fey et al., 2003; Cheung et al., 2004). S. aureus is commonly observed, colonizing several parts of the body in healthy individuals (Kiedrowski and Horswill, 2011) and causing associated biofilm infections (Balamurugan et al., 2017). The ability of $S$. aureus to form an extracellular slime and constitutive a biofilm assists this organism to endure the host immune response, thus impairing clinical treatment since biofilm formation defends bacteria from antimicrobial agents (Foster, 2005). Zingiber officinale has been used for thousands of years as a culinary and medicinal herb. A recent study has shown that Z. officinale has antibacterial activity against $S$. aureus, and that is higher than the antibiotics on the market (Kim and Park, 2013). The rhizome is rich in secondary metabolites such as phenolic compounds (gingerol, paradol, and shogunal), volatile sesquiterpenes (zingiberene and bisabolene) and monoterpenoids (curcumin and citral). Among herbal extracts, the inhibitory effect of $Z$. officinale extract on microorganisms has been well documented (Ali et al., 2008). Previous studies have demonstrated that isolated compounds from Z. officinale possess potent antioxidant, antibacterial, antifungal, anticancer, and antiinflammatory effects (Habib et al., 2008), as well as the impact of this extract on biofilm formation (Stoilova et al., 2007).

Quercetin, the most commonly studied flavonoid, has a wide range of biological activities, including antimicrobial activities (Hirai et al., 2010). Quercetin also influences quorum sensing, hence acts as an antibiofilm compound against $S$. aureus. It inhibits alginate production in a concentration-dependent manner, resulting in declination in the adherence during biofilm formation. It also reduces exopolysaccharide (EPS) production required for the initial attachment of bacteria. Some other reports also suggested that usinic acid show inhibitory effect on the $S$. aureus biofilm, and this has been hypothesized that this may be due to any interference in quorum sensing, but the exact mechanism of action is still indistinct (Roy et al., 2018). Based on quantification of the biofilm extracellular polymeric substances content and cell viability, quantitative proteome analyses and genome-scale metabolic modeling point to a vitamin $\mathrm{C}$-dependent inhibition of the synthesis of polysaccharides that form the biofilm matrix. This proceeds via inhibition of the quorum sensing and other regulatory mechanisms, leading to repression of specific biosynthetic operons. Once the EPS content is reduced beyond a critical point, bacterial cells become exposed and more susceptible to killing by any external factors (Pandit et al., 2017).

Ascorbic acid has been shown to be an effective antioxidant, acting both directly through aqueous peroxyl radical's reaction and indirectly through the restoration of the antioxidant properties of fat-soluble vitamin E. Interestingly, ascorbic acid has been reported to increase the effectiveness of antibiotics $v s$. a wide range of bacteria through a synergistic effect, but this synergy's mechanism remains unclear (Helgadóttir et al., 2017).

The main objective of this study was using $S$. aureus, a model biofilm-forming microorganism, also investigated the effects of $Z$. officinale extract, quercetin, and ascorbic acid on biofilm formation using a static biofilm assay. The distinction in the inhibition of biofilm between the culture containing $Z$. officinale extract and the control. 


\section{Materials and method}

\section{Clinical isolate repository}

In the period from July 2016 to March 2017, 157 samples taken from catheter patients received from the Rizgary Urinary Unit and Artificial Kidney Hospitals were investigated in Erbil City, Erbil, Iraq after cutting catheter (inside parts of the body) into $2 \mathrm{~cm}$ pieces and then incubating in brain heart infusion broth for 24-48 hrs. with shaking at $250 \mathrm{rpm}$, after that, the positive growth was cultured on Nutrient, Blood agar (BA), MacConkey and Mannitol Salt Agar (MSA) (Oxoid, UK).

\section{Culture and identification}

Primarily, isolates were cultured on MSA and BA (Oxoid, UK) and incubated at $37^{\circ} \mathrm{C}$ for $24 \mathrm{hrs}$. The assumed colonies of $S$. aureus were identified by using conventional methods; include gram staining, biochemical tests which comprise: catalase, oxidase, urease, coagulase using tube coagulase test (TCT) (Karasu and Rathish, 2014), gelatin liquefaction, hemolysis, staphyloxanthin and protease, tellurite reduction, lipase and lecithinase production, dextrose reduction, carbohydrate fermentation and tellurite reduction, and DNase with methyl green, followed by VITEK II Compact System (bioMérieux, Inc., France). Finally, identity of the isolates was confirmed via polymerase chain reaction (PCR) (Alpha PCRmax, UK) based on identifying $16 \mathrm{~S}$ rRNA and nuc genes. The sequences of both genes and PCR setup can be found in Table 1.

Table 1. Sequences of oligonucleotide primers used for PCR amplification of biofilmassociated genes with $16 S$ rRNA, nuc and mecA genes used in this study

\begin{tabular}{|c|c|c|c|c|}
\hline \multirow[b]{2}{*}{ Gene name } & \multicolumn{3}{|c|}{ Primers detail } & \multirow[b]{2}{*}{ References } \\
\hline & $\begin{array}{c}\text { Primer Sequence }\left(5^{\prime}-3^{\prime}\right) \\
\text { (Oligonucleotide) }\end{array}$ & $\begin{array}{l}\text { Amplicon } \\
\text { size (bp) }\end{array}$ & Cycling program & \\
\hline $16 \mathrm{~S}$ rRNA & $\begin{array}{l}\text { CAC CTT CCG ATA CGG CTA CC } \\
\text { GTT GAC TGC CGG TGA CAA AC }\end{array}$ & 372 & $\begin{array}{c}95^{\circ} \mathrm{C}-30 \mathrm{~s} ; 59^{\circ} \mathrm{C}-45 \mathrm{~s} ; 72^{\circ} \mathrm{C}- \\
1 \mathrm{~min} ; 35 \text { cycles }\end{array}$ & In this study \\
\hline пис & $\begin{array}{c}\text { GCG ATT GAT GGT GAT ACG GTT } \\
\text { AGC CAA GCC TTG ACG AAC TAA AGC }\end{array}$ & 279 & $\mid \begin{array}{c}95^{\circ} \mathrm{C}-30 \mathrm{~s} ; 53^{\circ} \mathrm{C}-45 \mathrm{~s} ; 72^{\circ} \mathrm{C}- \\
40 \mathrm{~s} ; 40 \text { cycles }\end{array}$ & $\begin{array}{l}\text { (Blaiotta et al., } \\
\text { 2004) }\end{array}$ \\
\hline mecA & $\begin{array}{l}\text { ATG TCT GCA GTA CCG GAG CTT T } \\
\text { AAA AT CGA TGG TAA AGG TTG GC }\end{array}$ & 533 & $\begin{array}{c}94^{\circ} \mathrm{C}-30 \mathrm{~s} ; 55^{\circ} \mathrm{C}-45 \mathrm{~s} ; 72^{\circ} \mathrm{C}- \\
1 \mathrm{~min} ; 40 \text { cycles }\end{array}$ & (Alli et al., 2015) \\
\hline$i c a A$ & $\begin{array}{l}\text { ACA CTT GCT GGC GCA GTC AA } \\
\text { TCT GGA ACC AAC ATC CAA CA }\end{array}$ & 188 & $\begin{array}{c}94^{\circ} \mathrm{C}-30 \mathrm{~s} ; 56^{\circ} \mathrm{C}-60 \mathrm{~s} ; 72^{\circ} \mathrm{C}- \\
45 \mathrm{~s} ; 30 \text { cycles }\end{array}$ & $\begin{array}{l}\text { (Kouidhi et al., } \\
\text { 2010) }\end{array}$ \\
\hline$i c a B$ & $\begin{array}{l}\text { CCC AAC GCT AAA ATC ATC GC } \\
\text { ATT GGA GTT CGG AGT GAC TGC }\end{array}$ & 1080 & $\begin{array}{c}95^{\circ} \mathrm{C}-30 \mathrm{~s} ; 58^{\circ} \mathrm{C}-30 \mathrm{~s} ; 72^{\circ} \mathrm{C}- \\
45 \mathrm{~s} ; 40 \text { cycles }\end{array}$ & $\begin{array}{l}\text { (Gowrishankar et } \\
\text { al., 2016) }\end{array}$ \\
\hline$i c a C$ & $\begin{array}{l}\text { CTT GGG TAT TTG CAC GCA TT } \\
\text { GCA ATA TCA TGC CGA CAC CT }\end{array}$ & 209 & $\begin{array}{c}95^{\circ} \mathrm{C}-30 \mathrm{~s} ; 55^{\circ} \mathrm{C}-40 \mathrm{~s} ; 72^{\circ} \mathrm{C}- \\
45 \mathrm{~s} ; 40 \text { cycles }\end{array}$ & $\begin{array}{l}\text { (Nourbakhsh and } \\
\text { Namvar, 2016) }\end{array}$ \\
\hline$i c a D$ & $\begin{array}{c}\text { ATG GTC AAG CCC AGA CAG AG } \\
\text { CGT GTT TTC AAC ATT TAA TGC AA }\end{array}$ & 198 & $\begin{array}{c}94^{\circ} \mathrm{C}-30 \mathrm{~s} ; 55^{\circ} \mathrm{C}-40 \mathrm{~s} ; 72^{\circ} \mathrm{C}- \\
45 \mathrm{~s} ; 30 \text { cycles }\end{array}$ & $\begin{array}{l}\text { (Kouidhi et al., } \\
\text { 2010) }\end{array}$ \\
\hline cna & $\begin{array}{l}\text { CGA TAA CAT CTG GGA ATA AA } \\
\text { ATA GTC TCC ACT AGG CAA CG }\end{array}$ & 716 & $\begin{array}{c}95^{\circ} \mathrm{C}-30 \mathrm{~s} ; 54^{\circ} \mathrm{C}-40 \mathrm{~s} ; 72^{\circ} \mathrm{C}- \\
45 \mathrm{~s} ; 35 \text { cycles }\end{array}$ & (Tang et al., 2011) \\
\hline atl & $\begin{array}{l}\text { GCC TGT TGC AAA GTC AAC AA } \\
\text { CAC CGA CAC CCC AAG ATA AG }\end{array}$ & 600 & $\mid \begin{array}{c}95^{\circ} \mathrm{C}-30 \mathrm{~s} ; 56^{\circ} \mathrm{C}-30 \mathrm{~s} ; 72^{\circ} \mathrm{C}- \\
45 \mathrm{~s} ; 40 \text { cycles }\end{array}$ & In this study \\
\hline$f n b A$ & $\begin{array}{l}\text { GAT ACA AAC CCA GGT GGT GG } \\
\text { TGT GCT TGA CCA TGC TCT TC }\end{array}$ & 191 & $\begin{array}{l}95^{\circ} \mathrm{C}-30 \mathrm{~s} ; 57^{\circ} \mathrm{C}-1 \mathrm{~min} \\
72^{\circ} \mathrm{C}-1 \mathrm{~min} ; 35 \text { cycles }\end{array}$ & $\begin{array}{l}\text { (Kouidhi et al., } \\
\text { 2010) }\end{array}$ \\
\hline$f n b B$ & $\begin{array}{l}\text { GAC CTG CTT CGC TAT CCA CA } \\
\text { AGT CGT AAT GGC GAC AGG TG }\end{array}$ & 980 & $\begin{array}{c}95^{\circ} \mathrm{C}-30 \mathrm{~s} ; 57^{\circ} \mathrm{C}-30 \mathrm{~s} ; 72^{\circ} \mathrm{C}- \\
1 \mathrm{~min} ; 40 \text { cycles }\end{array}$ & In this study \\
\hline
\end{tabular}

\section{Antimicrobial susceptibility screening}

According to the references of the Clinical and Laboratory Standards Institute (CLSI) (CLSI, 2017), antimicrobial sensitivity testing was carried out against the following antimicrobials using disk diffusion method; Amikacin AK $30 \mu \mathrm{g}$, Azithromycin AZM 
$15 \mu \mathrm{g}$, Ciprofloxacin CIP $5 \mu \mathrm{g}$, Clindamycin CD $2 \mu \mathrm{g}$, Erythromycin E $15 \mu \mathrm{g}$, Gentamicin G $10 \mu \mathrm{g}$, Levofloxacin LEV $5 \mu \mathrm{g}$, Netilmicin NET $30 \mu \mathrm{g}$, Nitrofurantoin NIT $300 \mu \mathrm{g}$, Norfloxacin NOR $10 \mu \mathrm{g}$, Oxacillin OX $1 \mu \mathrm{g}$, Penicillin P $10 \mathrm{U}$, Tetracycline TE $30 \mu \mathrm{g}$, Tobramycin TOB $10 \mu \mathrm{g}$, Trimethoprim+Sulfamethoxazole SXT 1.25+23.75 $\mu \mathrm{g}$, and Vancomycin VA $30 \mu \mathrm{g}$ (Bioanalyse, Turkey). A lawn of test S. aureus was prepared by evenly spreading $100 \mu \mathrm{L}$ inoculums $\left(1.5 * 10^{8} \mathrm{CFU} / \mathrm{ml}\right)$ according to $0.5 \mathrm{McF}$ arland (1907) standard solution with the sterilized swab on top of the entire surface of Mueller Hinton Agar plate (Oxoid, UK). The disks were resolutely applied onto the agar plates surface within 15 minutes of inoculation (Bimanand et al., 2018).

\section{Assessment of biofilm synthesis by S. aureus}

\section{Congo red agar method}

Phenotypical biofilm production in all $S$. aureus isolates was evaluated through culturing CRA plates and explained by (Szczuka et al., 2013; Khoramrooz et al., 2016). First of all, they prepared CRA plates by adding $0.8 \mathrm{~g}$ of Congo red (Merck, Germany) and $36 \mathrm{~g}$ of sucrose (Sigma, USA) to one liter of brain heart infusion agar (BHI) (Merck, Germany). The plates have been incubated for 24 hours at $37^{\circ} \mathrm{C}$. The morphology of colonies was then interpreted based on colony color as Bordeaux pink (red), almost black, black, and strong black. Strains with red colonies were classified as strains that are unable to produce biofilm, while nearly black color indicated a weak activity in biofilm production. Whereas, colonies that were very black and black were considered strong strains of biofilm producers.

\section{Polystyrene microtiter plate assay}

Biofilm production was quantitatively determined through an MTP method as defined by Yousefi et al. (2016). In short, bacterial isolates were grown with 0.5 percent glucose in trypticase soy broth (TSB) (Merck, Germany) and incubated at $37^{\circ} \mathrm{C}$ overnight. Cultures with 0.5 percent glucose with 1:40 in fresh TSB were diluted (Sigma, USA). Two hundred $\mu \mathrm{L}$ of the diluted solution was added to Microtiter plate wells and incubated at $37^{\circ} \mathrm{C}$ for $48 \mathrm{hrs}$. The negative control wells contained only $200 \mu \mathrm{L}$ of TSB- $0.5 \%$ glucose without bacterial suspension. Wells were gently washed with phosphate buffer saline (PBS) (pH 7.2) three times and fixed with methanol for 20 minutes, dried at room temperature, then stained with crystal violet 0.1 percent. The dye attached to the adhering cells was dissolved with $1 \mathrm{~mL}$ of $95 \%$ ethanol per well. Finally, optical density (OD) was obtained at $570 \mathrm{~nm}\left(\mathrm{~A}_{570}\right)$ for each well using ELISA reader (BioTek ELx800, USA). The average OD of negative control +3 standard deviation (SD) of negative control was calculated for the optical density cut-off (ODc). Based on the absorbance of crystal violet stain linked to the adhered cells, biofilms formed by various strains have been analyzed and categorized (Table 2).

Table 2. Classification of biofilm formation abilities by Microtiter plate method

\begin{tabular}{c|c|c}
\hline Cut-off value calculation & Mean of OD $_{\mathbf{5 7 0}}$ values results & Biofilm formation abilities \\
\hline $\mathrm{OD}>4 \times \mathrm{ODc}$ & $\mathrm{OD}>0.557$ & Strong \\
$2 \times \mathrm{ODc}<\mathrm{OD} \leq 4 \times \mathrm{ODc}$ & $0.278<\mathrm{OD} \leq 0.557$ & Moderate \\
$\mathrm{ODc}<\mathrm{OD} \leq 2 \times \mathrm{ODc}$ & $0.139<\mathrm{OD} \leq 0.278$ & Weak \\
$\mathrm{OD} \leq 0.139$ & $\mathrm{OD} \leq 0.139$ & None \\
\hline
\end{tabular}




\section{Genomic DNA extraction}

According to the manufacturer's instructions, genomic DNA was extracted from pure cultures through the Presto ${ }^{\mathrm{TM}}$ Mini gDNA Bacteria Kit (Geneaid, Taiwan); extract was eluted with an elution buffer of $100 \mu \mathrm{L}$. Before running PCR, extracts were stored at $-20^{\circ} \mathrm{C}$. The NanoDrop 1000 spectrophotometer (ThermoFisher Scientific, USA) was used to evaluate DNA concentration and purity in which one $\mu \mathrm{L}$ of the genome DNA was used to define DNA concentration and purity.

\section{PCR screening of biofilm genetic determinants}

In our research, detection in $S$. aureus isolates for biofilm-related genes was carried out using the PCR technique. The final volume of the PCR reaction was $25 \mu \mathrm{L}$ using $12.5 \mu \mathrm{L}$ of $2 \mathrm{x}$ HotStart Taq Master Mix, one $\mu \mathrm{L}$ of the DNA template, one $\mu \mathrm{L}$ of each primer $(20 \mathrm{pmol})$ and $9.5 \mu \mathrm{L}$ of $\mathrm{ddH}_{2} \mathrm{O}$. DNA amplification was done in a thermocycler PCR. Primers and amplification conditions for PCR programs are mentioned in Table 1. Amplified products were subjected to electrophoresis using 1.2\% agarose (GeNet Bio, Korea) gel containing 1x GelRed DNA stain.

\section{Ferric Reducing Antioxidant Power (FRAP) assay}

To be able to measure the ferric reduction activity of our samples, the test was performed based on Benzie and Strain (1996). The FRAP solution was freshly prepared by combination of acetate buffer $(0.3 \mathrm{Mol} / \mathrm{L})(\mathrm{pH}=3.6), 2,4$, 6-tripyridyltriazine (TPTZ) $\left(0.01 \mathrm{Mol} / \mathrm{L}\right.$ in $\mathrm{HCl}(0.04 \mathrm{Mol} / \mathrm{L})$ and $\mathrm{FeCl}_{3}(0.02 \mathrm{Mol} / \mathrm{L})(10: 1: 1)$ by volume, respectively. The test was performed by placing $100 \mu \mathrm{L}$ of the tested chemicals in a test tube (Conc. $1 \mathrm{mg} / \mathrm{mL}$ ) and $2 \mathrm{~mL}$ of the FRAP reagent, the samples were continuously shaken and leave in the dark place for 30 min. Then the absorbance at $593 \mathrm{~nm}$ was recorded. The standard ascorbic acid curve was prepared for comparison using various concentrations, as shown in Fig. 1. The FRAP value calculated by Equation 1 for each compound. In this study, the test solution's yellow color reduces ferric complex with TPTZ (less color) to ferrous complex with TPTZ (violet color) changes to different shades of violet depending on each compound's reduced power. The higher reduction potential was determined by higher absorbance of the reaction mixture.

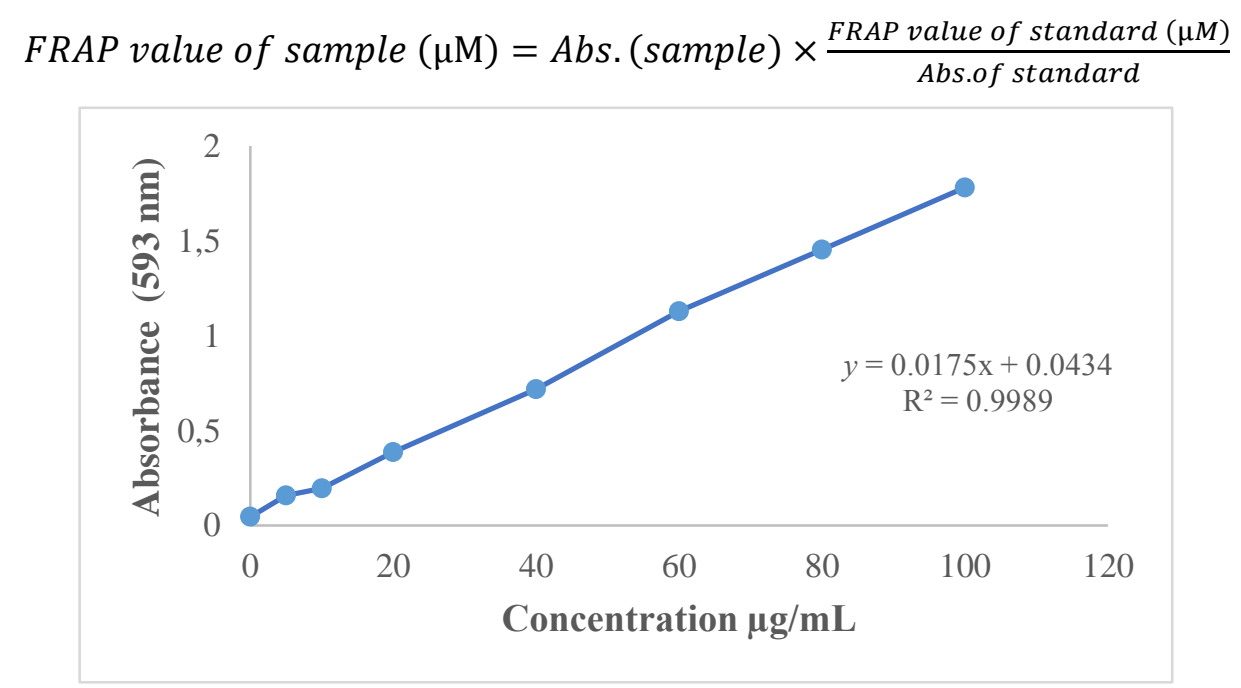

Figure 1. The standard curve of ascorbic acid 


\section{Biofilm formation inhibition test}

\section{Preparation of $Z$. officinale extract}

Z. officinale extract was prepared under the protocol described by Kim and Park (2013). In short, $150 \mathrm{~g}$ of shredded rhizome of Z. officinale was mixed with $300 \mathrm{~mL}$ toluene. The debris was allowed to settle at room temperature for $24 \mathrm{hrs}$. A Whatman No. 1 filter paper (pore size $=11 \mu \mathrm{m}$ ) had been used for filtration of the supernatant. Then the mixture was stirred for $24 \mathrm{hrs}$. at room temperature using a magnetic stirrer. Then the mixture was left to form phases of water and toluene. Using a pipette, the water phase was collected and filtered through a $0.22 \mu \mathrm{m}$ microfilter. The filtrate $(100 \% \mathrm{Z}$. officinale extract) was used to test if $Z$. officinale extract inhibits the formation of biofilms.

\section{Antimicrobial activity of quercetin}

The antimicrobial activity of quercetin was performed by the microdilution method, already described previously, according to the CLSI. The range of concentration of quercetin used in this study was 2 to $256 \mu \mathrm{g} / \mathrm{ml}$ (Sérgio et al., 2018). The experiment was performed in triplicate.

\section{Preparation and dilution of ascorbic acid}

One milligram of ascorbic acid was dissolved in $1 \mathrm{ml}$ of TSB medium to get a stock solution of $1000 \mu \mathrm{g} / \mathrm{ml}$. Final concentrations of 2, 4, 8, 16, 32, 64, 128, and $256 \mu \mathrm{g} / \mathrm{ml}$ were obtained through serial dilutions to explore the antibiofilm activity against $S$. aureus. Ascorbic acid was mixed for two minutes with TSB medium and vortex. It was covered with aluminum foil to prevent light. At the time of their use, all solutions were prepared.

\section{Static biofilm formation assay}

To test the effect of plant extract on biofilm formation, a modified crystal violet assay was used. In sterile 96 well plates containing $50 \mu \mathrm{L}$ of nutrient broth per well, two-fold serial dilutions of compounds were made. The concentration range of the compounds tested is 2 to $256 \mu \mathrm{g} / \mathrm{mL}$ in separate wells. Each well was supplemented with a $50 \mu \mathrm{L}$ fresh bacterial suspension $(0.5 \mathrm{McFarland})$ with growth control (cells + broth). The biofilm biomass was tested using the crystal violet staining assay after incubation at $37^{\circ} \mathrm{C}$ for $48 \mathrm{~h}$ (Kim and Park, 2013). The biofilm inhibition percentage was calculated using Equation 2.

$$
\text { Biofilm inhibition } \%=\frac{\text { oD growth control }- \text { OD sample }}{\text { OD growth control }} \times 100
$$

\section{Data analysis}

For statistical analysis, the Social Science Statistical Package (SPSS 24.0) software (SPSS Inc., USA) was used. The statistical significance was assessed through Turkey's multiple comparisons; the test was used to analyze the association between phenotypic biofilm formation methods and biofilm-related genes, and also the significant difference in biofilm inhibition percentage between active, positive-controlled biofilm producers and $p$-value $<0.05$ was considered statistically significant. 


\section{Results}

\section{Isolation and characterization of S. aureus}

Based on biochemical tests, isolates from one hundred catheter specimens (63.69\%) were identified as $S$. aureus (Table 3). The strains were from samples belonging to 67 male patients (67\%), and 33 female patients (33\%). To support the identification of $S$. aureus isolates by a conventional method, VITEK II Compact System was performed, and all strains of $S$. aureus were reidentified by this system, some results contradicted the traditional tests and identified a different staphylococcal species than $S$. aureus. The present findings of the VITEK II system show that 83 isolates were identified as $S$. aureus among 100 isolates that were identified in the conventional method, and the remaining strains identified were xylosus $(n=6)$, sciuri $(n=6)$, vitulinus $(n=1)$, warneri $(n=1)$, lentus $(n=1)$, hemolytics $(n=1)$, and gallinarum $(n=1)$. To further confirm the identity of the isolates, all $S$. aureus were examined for the presence of the $16 S$ rRNA and nuc genes to characterize and validate the $S$. aureus. All of the strains were confirmed as $S$. aureus by the occurrence of $16 S$ rRNA, and nuc genes (Fig. 2). About two-thirds of catheter-isolated bacteria were identified as $S$. aureus.

Table 3. The morphological, cultural, biochemical, and molecular tests for the identification of $S$. aureus isolates

\begin{tabular}{|c|c|c|c|}
\hline \multirow[b]{2}{*}{ Biochemical tests } & \multicolumn{2}{|c|}{ Positive $S$. aureus } & \multirow{2}{*}{$\begin{array}{c}\text { Positive\% among catheter } \\
\text { specimens }(n=157)\end{array}$} \\
\hline & $\begin{array}{c}\text { Positive } \\
\text { n. }(\%)\end{array}$ & $\begin{array}{c}\text { Negative } \\
n .(\%)\end{array}$ & \\
\hline Mannitol fermentation & $100(100)$ & $\mathbf{0}(0)$ & 63.69 \\
\hline Coagulase HP & $91(91)$ & $9(9)$ & 57.95 \\
\hline Coagulase RP & $96(96)$ & $4(4)$ & 61.14 \\
\hline Catalase & $100(100)$ & $\mathbf{0}(0)$ & 63.69 \\
\hline Oxidase & $\mathbf{0}(0)$ & $100(100)$ & 0 \\
\hline Urease & $54(54)$ & $46(46)$ & 34.39 \\
\hline Gelatinase & $100(100)$ & $\mathbf{0}(0)$ & 63.69 \\
\hline$\beta$ Hemolysis & $71(71)$ & $\ldots$ & 45.21 \\
\hline$\alpha$ Hemolysis & $2(2)$ & $\ldots$ & 1.27 \\
\hline$\gamma$ Hemolysis & $27(27)$ & $\ldots$ & 17.19 \\
\hline DNase & $100(100)$ & $\mathbf{0}(0)$ & 63.69 \\
\hline Staphyloxanthin & $85(85)$ & $15(15)$ & 54.13 \\
\hline Caseinase & $82(82)$ & $18(18)$ & 52.22 \\
\hline Tellurite reduction & $100(100)$ & $\mathbf{0}(0)$ & 63.69 \\
\hline Shiny colonies & $100(100)$ & $\mathbf{0}(0)$ & 63.69 \\
\hline Lipase activities & $64(64)$ & $36(36)$ & 40.76 \\
\hline Lecithinase production & $62(62)$ & $38(38)$ & 39.48 \\
\hline VITEK II System & $\mathbf{8 3}(83)$ & $17(17)$ & 52.86 \\
\hline $16 S r R N A$ gene & $100(100)$ & $\mathbf{0}(0)$ & 63.69 \\
\hline$n u c$ gene & $100(100)$ & $\mathbf{0}(0)$ & 63.69 \\
\hline
\end{tabular}

\section{Susceptibility patterns of S. aureus against different antimicrobials}

The results of the antimicrobial sensitivity test for all $S$. aureus isolates against 16 antimicrobials demonstrated various sensitivity patterns (Table 4). The highest resistant percentage recorded was against oxacillin (99\%), followed by penicillin (97\%). However, the lowest resistant $1 \%$ recorded was against each of gentamycin, nitrofurantoin, and trimethoprim-sulfamethoxazole. 


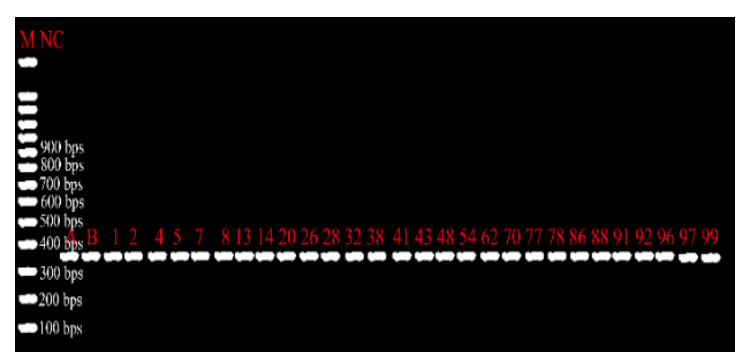

A

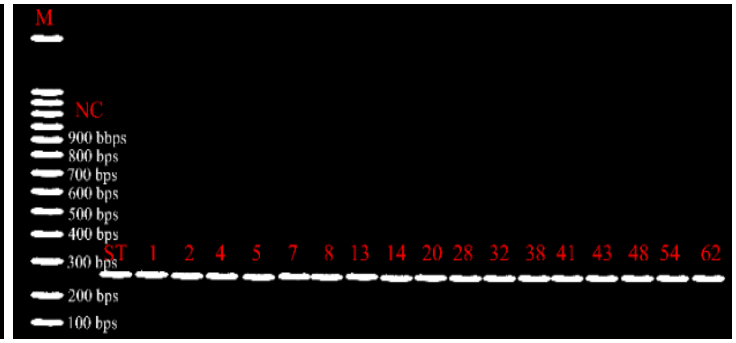

B

Figure 2. Agarose gel electrophoresis of PCR amplification products of S. aureus. A: 16S rRNA gene, M: The DNA marker (100 bp ladder), lane A and B: S. aureus ATCC 23925, lanes (1-99) positive amplification of 372 bp for $16 S$ rRNA gene. B: nuc gene, M: The DNA marker (100 bp ladder), lane NC: S. epidermidis ATCC 22922, lane ST: S. aureus ATCC 23925, lanes (1-62) positive amplification of $279 \mathrm{bp}$ for nuc gene

Table 4. Susceptibility patterns of S. aureus isolate toward antimicrobials

\begin{tabular}{c|c|c|c}
\hline Antimicrobials & Resistance & Intermediate & $\begin{array}{c}\text { Sensitivity } \\
\boldsymbol{n} .(\%)\end{array}$ \\
\hline AK* $(\%)$ & $\mathbf{n .}(\%)$ & $\mathbf{9 8}(98)$ \\
AZM & $\mathbf{1}(1)$ & $\mathbf{1}(1)$ & $\mathbf{4 9}(49)$ \\
CIP & $\mathbf{4 7}(47)$ & $\mathbf{4}(4)$ & $\mathbf{8 8}(88)$ \\
CD & $\mathbf{1 1}(11)$ & $\mathbf{1}(1)$ & $\mathbf{5 1}(51)$ \\
E & $\mathbf{3 0}(30)$ & $\mathbf{1 9}(19)$ & $\mathbf{4 1}(41)$ \\
G & $\mathbf{5 3}(53)$ & $\mathbf{6}(6)$ & $\mathbf{9 5}(95)$ \\
LEV & $\mathbf{1}(1)$ & $\mathbf{4}(4)$ & $\mathbf{9 1}(91)$ \\
NET & $\mathbf{9}(9)$ & $\mathbf{0}(0)$ & $\mathbf{9 6}(96)$ \\
NIT & $\mathbf{1}(1)$ & $\mathbf{3}(3)$ & $\mathbf{7 8}(78)$ \\
NOR & $\mathbf{2 1}(21)$ & $\mathbf{1}(1)$ & $\mathbf{5 8}(58)$ \\
OX & $\mathbf{1 8}(18)$ & $\mathbf{3 4}(34)$ & $\mathbf{1}(1)$ \\
P & $\mathbf{9 9}(99)$ & $\mathbf{0}(0)$ & $\mathbf{3}(3)$ \\
TE & $\mathbf{9 7}(97)$ & $\mathbf{0}(0)$ & $\mathbf{7 4}(74)$ \\
TOB & $\mathbf{2 3}(23)$ & $\mathbf{3}(3)$ & $\mathbf{7 8}(78)$ \\
SXT & $\mathbf{1 9}(19)$ & $\mathbf{3}(3)$ & $\mathbf{9 1}(91)$ \\
VA & $\mathbf{1}(1)$ & $\mathbf{8}(8)$ & $\mathbf{4 7}(47)$ \\
\hline
\end{tabular}

*: AK: Amikacin, AZM: Azithromycin, CIP: Ciprofloxacin, CD: Clindamycin, E: Erythromycin, G: Gentamicin, LEV: Levofloxacin, NET: Netilmicin, NIT: Nitrofurantoin, NOR: Norfloxacin, OX: Oxacillin, P: Penicillin, TE: Tetracycline, TOB: Tobramycin, SXT: Trimethoprim+Sulfamethoxazole, and VA: Vancomycin

\section{Biofilm formation through microtiter plate test}

The ability to form a biofilm was evaluated using the MTP described elsewhere (Yousefi et al., 2016). In this study, OD $_{570}$ mean of microplate readings after crystal violet staining ranged from 0.216 to 0.827 . The mean of negative control was 0.054. An ODc 570 of biofilm formation was defined as 0.139 . The strains were divided into four groups: non-biofilm producer $(-), \mathrm{OD}_{570} \leq 0.139$; weak biofilm producer $(+), 0.139<\mathrm{OD}_{570} \leq 0.278$; moderate biofilm producer $(++), 0.278<\mathrm{OD}_{570} \leq 0.557$; strong biofilm producer $(+++)$, $0.557 \leq \mathrm{OD}_{570}$. Our data shows that $100 \%$ of $S$. aureus isolates were positive for biofilms, $21 \%$ of which were recorded as a strong producer of biofilms $(n=21), 71 \%$ as a moderate producer of biofilms $(n=71)$ and $8 \%$ as a weak producer of biofilms $(n=8)$. 


\section{Biofilm formation determination by Congo red agar test}

In vitro biofilm formation by the CRA method differs from MTP assay. Results show that $49 \%$ of the isolates $(n=49)$ demonstrated strong biofilm formation (strong black), $15 \%$ were moderate biofilm producer, $25 \%$ weak biofilm producer, and $11 \%$ of the isolates were classified as non-biofilm producer. Statistically, there is not a significant difference ( $p=0.8997)$ between the total percent formation in both MTP assay, and CRA methods for the detection of phenotypic biofilm formation among isolates of $S$. aureus was observed (Table 5). While there are highly significant differences among biofilm formation status when compared between both MTA assay and CRA method (Fig. 3).

Table 5. Screening of S. aureus isolates from biofilm production by CRA and MPM assay

\begin{tabular}{c|c|c|c}
\hline \multirow{2}{*}{ Biofilm formation status } & \multicolumn{2}{|c|}{ Screening method } & \multirow{2}{*}{$\boldsymbol{P}$-value } \\
\cline { 2 - 3 } & CRA $\boldsymbol{n}$. $(\%)$ & MTP $\boldsymbol{n}$. $(\%)$ & \\
Strong & $\mathbf{4 9}(49 \%)$ & $\mathbf{2 1}(21 \%)$ & \multirow{2}{*}{$=0.8997$} \\
Moderate & $\mathbf{1 5}(15 \%)$ & $\mathbf{8}(8 \%)$ & \\
Weak & $\mathbf{2 5}(25 \%)$ & $\mathbf{0}(0 \%)$ & \\
None & $\mathbf{1 1}(11 \%)$ & $\mathbf{1 0 0}(100 \%)$ & \\
Total & $\mathbf{8 9}(89 \%)$ &
\end{tabular}

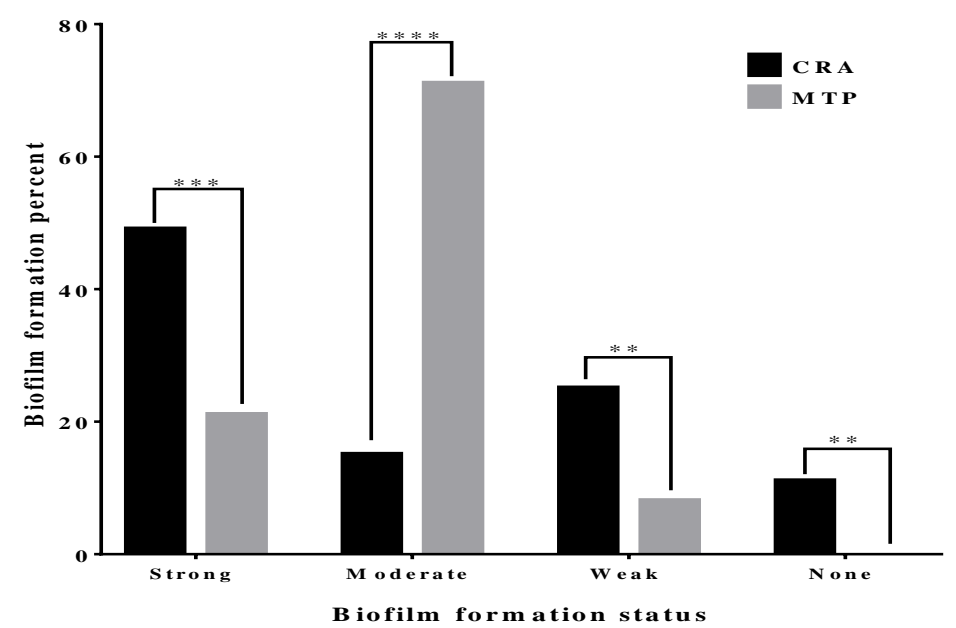

Figure 3. Comparison of biofilm formation status

\section{Detection of genes involved in biofilm formation}

PCR assay was used to detect icaA, icaB, icaC, icaD, cna, atl, fnbA, and $f n b B$ genes among the primary intention of this study are the genotypically characterization of biofilm responsible genes. Ninety-six percent of $S$. aureus isolates have been selected for this purpose. We evaluated the relationship between the formation of biofilm and the eight genes associated with biofilm. The distribution of these genes in S. aureus isolates is illustrated in Table 6 . All of the eight genes were detected among isolates with different frequencies. As can be seen, the majority of $S$. aureus isolates $(96 \%[n=24])$ were found to be positive for the icaC and cna gene (Fig. 4). The prevalence rates of the icaA, icaB, $i c a D$, atl, $f n b A$, and $f n b B$ genes were unswervingly found to be $76 \%, 68 \%, 88 \%, 92 \%$, $84 \%$, and $80 \%$, respectively. Nine of the isolates $(36 \%)(n=9)$ that were biofilm producers were shown to possess all of the eight genes aimed to detect in the current study. A 
significant association was only observed between the presence of $i c a B$ gene $(p=0.028)$ and phenotypic biofilm formation in $S$. aureus isolates, while non-significant association was noticed for each of icaA $(p=0.2085)$, icaC $(p=0.9894)$, icaD $(p=0.7238)$, cna $(p=0.9894)$, atl $(p=0.9004)$, fnbA $(p=0.5207)$ and $f n b B(p=0.3421)$ and phenotypic biofilm formation features.

Table 6. Relationships between biofilm-related genes and biofilm formation detection (MTP assay and CRA method) in S. aureus isolates

\begin{tabular}{|c|c|c|c|c|c|c|c|c|c|c|c|c|}
\hline \multirow{2}{*}{ Isolates } & \multicolumn{2}{|c|}{$\begin{array}{c}\text { In vitro Adherence (MTP) } \\
\text { Assay }\end{array}$} & \multicolumn{2}{|c|}{ CRA method } & \multicolumn{8}{|c|}{ Presence of biofilm-related genes } \\
\hline & \begin{tabular}{|c|} 
Adherence \\
$\mathbf{A}_{570} \mathbf{~} \mathrm{m}$ Mean
\end{tabular} & $\begin{array}{l}\text { Adherence } \\
\text { Ability }\end{array}$ & $\begin{array}{c}\text { Biofilm } \\
\text { phenotype }\end{array}$ & $\begin{array}{l}\text { Biofilm } \\
\text { producer }\end{array}$ & $i c a A$ & $i c a B$ & icaC & icaD & cna & atl & $f n b A$ & $f n b B$ \\
\hline SA01 & 0.236 & + & Black** & Producer & + & + & + & + & + & + & - & + \\
\hline SA02 & 0.488 & ++ & Strong Black & Producer & + & - & + & - & + & + & + & + \\
\hline SA04 & 0.608 & +++ & Strong Black & Producer & + & - & + & + & + & + & - & + \\
\hline SA05 & 0.379 & ++ & Strong Black & Producer & + & + & + & + & + & + & + & + \\
\hline SA07 & 0.578 & +++ & Black & Producer & - & + & + & + & + & + & + & + \\
\hline SA08 & 0.402 & ++ & Black & Producer & + & + & + & + & + & + & + & - \\
\hline SA13 & 0.491 & ++ & Almost Black & Producer & - & - & + & + & + & + & + & + \\
\hline SA14 & 0.586 & +++ & Almost Black & Producer & + & + & + & - & + & + & + & - \\
\hline SA20 & 0.216 & + & Bordeaux pink & Nonproducer & + & + & + & + & + & + & + & + \\
\hline SA26 & 0.552 & ++ & Almost Black & Producer & + & + & + & + & + & + & - & + \\
\hline SA28 & 0.297 & ++ & Almost Black & Producer & + & + & + & + & + & + & + & + \\
\hline SA32 & 0.36 & ++ & Strong Black & Producer & - & + & + & + & + & + & + & + \\
\hline SA38 & 0.318 & ++ & Bordeaux pink & Nonproducer & - & - & + & + & + & + & + & + \\
\hline SA41 & 0.379 & ++ & Strong Black & Producer & + & + & + & + & + & + & + & + \\
\hline SA43 & 0.317 & ++ & Strong Black & Producer & + & + & + & + & + & + & + & + \\
\hline SA48 & 0.667 & +++ & Strong Black & Producer & + & + & + & + & + & - & + & - \\
\hline SA49 & 0.376 & ++ & Bordeaux pink & Nonproducer & - & - & - & - & - & - & + & - \\
\hline SA5 & 0.26 & + & Black & Producer & + & - & + & + & + & + & - & + \\
\hline SA62 & 0.458 & ++ & Strong Black & Producer & + & + & + & + & + & + & + & + \\
\hline SA70 & 0.349 & ++ & Strong Black & Producer & + & + & + & + & + & + & + & + \\
\hline SA77 & 0.36 & ++ & Strong Black & Producer & + & - & + & + & + & + & + & + \\
\hline SA78 & 0.383 & ++ & Almost Black & Producer & + & + & + & + & + & + & + & + \\
\hline SA86 & 0.425 & ++ & Strong Black & Producer & + & + & + & + & + & + & + & - \\
\hline SA88 & 0.352 & ++ & Strong Black & Producer & - & - & + & + & + & + & + & + \\
\hline SA93 & 0.284 & ++ & Strong Black & Producer & + & + & + & + & + & + & + & + \\
\hline Total positive & \multirow{3}{*}{\multicolumn{2}{|c|}{$\begin{array}{c}25 \\
100\end{array}$}} & \multirow{3}{*}{\multicolumn{2}{|c|}{$\begin{array}{c}22 \\
88 \\
0.8997\end{array}$}} & 19 & 17 & 24 & 22 & 24 & 23 & 21 & 20 \\
\hline Percent & & & & & 76 & 68 & 96 & 88 & 96 & 92 & 84 & 80 \\
\hline$P$-value & & & & & 0.2085 & 0.028 & 0.989 & 0.7238 & 0.9894 & 0.900 & 0.5207 & 0.3421 \\
\hline
\end{tabular}

*: indicates the varied adhering ability of S. aureus isolates, where strong black colonies; strong biofilm producer, black colonies; moderate biofilm producer, almost black colonies; weak biofilm producer, Bordeaux pink colonies; non - biofilm producer, also +: weak biofilm producer. ++: moderate biofilm producer. +++ : strong biofilm producer. ${ }^{1}$ : ODC: mean +3 standard deviation of negative control in microplate. $\mathrm{ODC}=0.139,2 \mathrm{ODC}=0.278,4 \mathrm{ODC}=0.556$

\section{FRAP reducing power}

The antioxidant activity of the Z. officinale, quercetin, and ascorbic acid was measured by FRAP assay and has been presented in Table 7. It shows that electron-donating groups enhanced reducing power. Quercetin indicates that they are most effective electron donor and can reduce the oxidized intermediates highly reactive molecules like free radicals and reactive oxygen species of peroxidation processes and the FRAP value $10406.4 \mu \mathrm{M} / \mathrm{g}$ while the $Z$. officinale extract has low antioxidant activity (FRAP value $=5420.8 \mu \mathrm{M} / \mathrm{g}$ ) when compared with both quercetin and ascorbic acid. Ascorbic acid usually used as a standard for preparing the standard curve and has high antioxidant activity (FRAP value $=8379.5 \mu \mathrm{M} / \mathrm{g}$ ) 


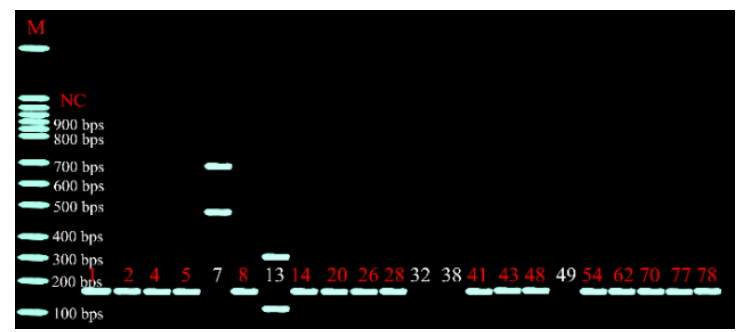

A. icaA

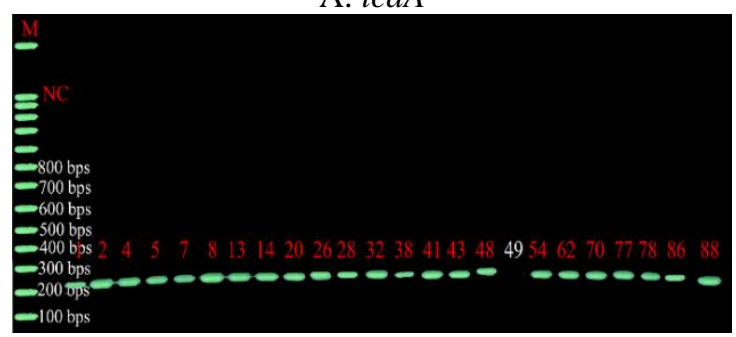

C. icaC

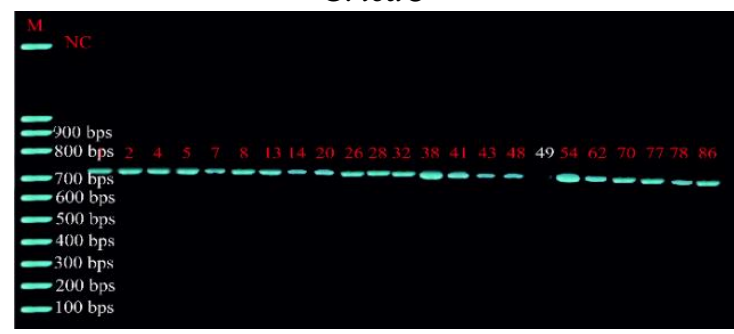

E. cna

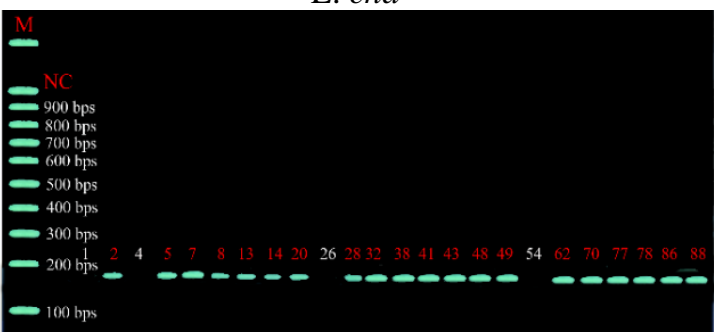

G. $f n b A$

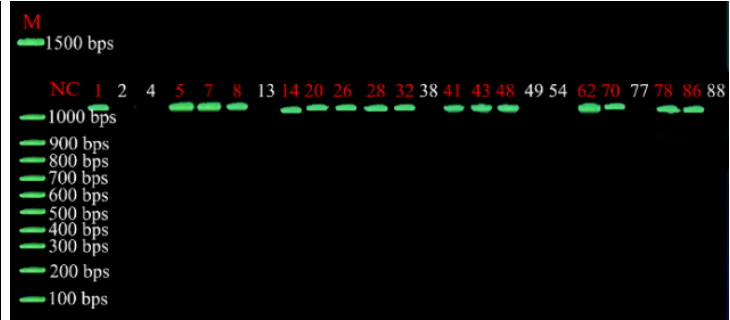

B. $i c a B$

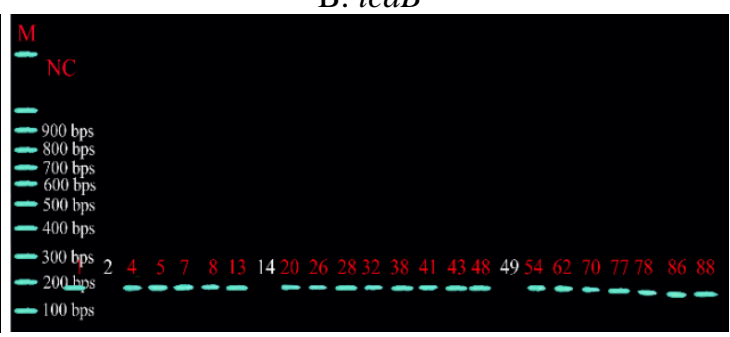

D. icaD

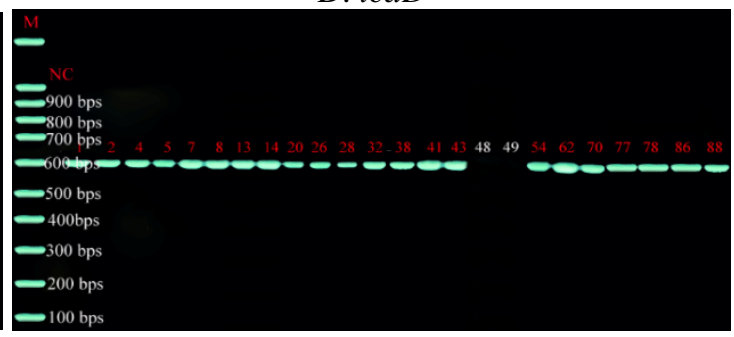

F. atl

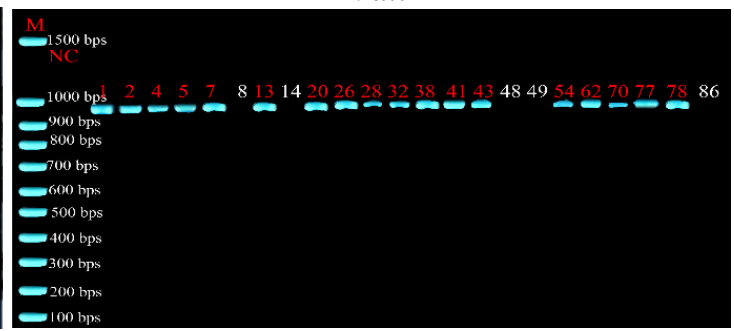

H. $f n b B$

Figure 4. Agarose gel electrophoresis graphic of PCR amplification for biofilm-related genes in S. aureus isolates

Table 7. Anti-oxidant activity of the Z. officinale, quercetin and ascorbic acid measured by FRAP assay

\begin{tabular}{c|c|c|c|c}
\hline \multirow{2}{*}{ Compounds } & \multirow{2}{*}{ Absorbance } & \multicolumn{3}{|c}{ FERAP value } \\
\cline { 3 - 5 } & & $\boldsymbol{\mu M}$ & $\boldsymbol{\mu M} / \mathbf{m g}$ & $\boldsymbol{\mu M} / \mathbf{g}$ \\
\hline Z. officinale & 1.507 & 54.208 & 542.08 & 5420.8 \\
Quercetin & 2.893 & 104.064 & 1040.64 & 10406.4 \\
Ascorbic acid & 2.327 & 83.705 & 837.05 & 8370.5 \\
\hline
\end{tabular}

\section{Effect of Z. officinale extract on biofilm formation}

A static biofilm quantification assay was performed to evaluate the effect of $Z$. officinale extract on five strong biofilm isolates of $S$. aureus. Table 8 shows the difference in biofilm inhibition between the culture containing $Z$. officinale extract and the control (i.e., no Z. officinale extract addition). The high biofilm inhibition percent 
were 61.4 at concentration $16 \%$ against SA04 while there is no any effect on biofilm formation at concentrations 4, 2, 1, and 0.5\% against each of SA36, and SA62 isolates. Significantly, there were differences in biofilm reduction for Z. officinale extract at concentration 32,16 , and $8 \%(p=0.0458, p=0.0391$, and $p=0.0247$, respectively). In spite of decreasing of biofilm formation, there were no observed significant at concentrations $64,4,2,1$, and $0.5 \%(p=0.1015, p=0.1676, p=0.8017, p=0.8811$, and $p=0.5925$, respectively). The inhibition of $Z$. officinale extract to biofilm formation was not due to minor toluene contamination or something extracted from the glassware during the preparation of $Z$. officinale extract, which was confirmed by an experiment using mock extraction.

Table 8. Antibiofilm potency of Z. officinale, quercetin and ascorbic acid

\begin{tabular}{|c|c|c|c|c|c|c|c|c|c|}
\hline \multirow{2}{*}{ Isolates } & \multicolumn{8}{|c|}{ \% of Biofilm Inhibitors of Z. officinale (\%) } & \multirow{2}{*}{$\begin{array}{c}\text { Growth Control } \\
\text { (OD) }\end{array}$} \\
\hline & 64 & 32 & 16 & 8 & 4 & 2 & 1 & 0.5 & \\
\hline SA04 & 54 & 59 & 61.4 & 57 & 41 & 41 & 47 & 9.7 & 0.131 \\
\hline SA36 & 14 & 28 & 36.4 & 36 & 0 & 0 & 0 & 0 & 0.109 \\
\hline SA48 & 36 & 47 & 43.1 & 45 & 30 & 0 & 17 & 43 & 0.108 \\
\hline SA62 & 47 & 46 & 45 & 45 & 46 & 0 & 0 & 0 & 0.143 \\
\hline SA86 & 47 & 45 & 47.4 & 46 & 46 & 30 & 0.9 & 40 & 0.157 \\
\hline$P$ value & 0.1015 & 0.0458 & 0.0391 & 0.0247 & 0.1676 & 0.8017 & 0.8811 & 0.5925 & \\
\hline \multirow{2}{*}{ Isolates } & \multicolumn{8}{|c|}{ \% of Biofilm Inhibitors of Quercetin $(\mu \mathrm{g} / \mathrm{mL})$} & \multirow{2}{*}{$\begin{array}{l}\text { Growth Control } \\
\text { (OD) }\end{array}$} \\
\hline & 256 & 128 & 64 & 32 & 16 & 8 & 4 & 2 & \\
\hline SA04 & 18 & 76 & 79.4 & 58 & 56 & 48 & 43 & 40 & 0.139 \\
\hline SA36 & 25 & 31 & 0 & 92 & 20 & 43 & 43 & 45 & 0.134 \\
\hline SA48 & 23 & 16 & 0 & 52 & 34 & 41 & 41 & 38 & 0.155 \\
\hline SA62 & 34 & 38 & 20.3 & 57 & 55 & 41 & 41 & 36 & 0.137 \\
\hline SA86 & 24 & 48 & 28.7 & 59 & 59 & 61 & 61 & 62 & 0.15 \\
\hline P value & 0.0221 & 0.1426 & 0.6646 & 0.0041 & 0.0855 & 0.0221 & 0.0246 & 0.0369 & \\
\hline \multirow{2}{*}{ Isolates } & \multicolumn{8}{|c|}{ \% of Biofilm Inhibitors of Vitamin $C(\mu \mathrm{g} / \mathrm{mL})$} & \multirow{2}{*}{$\begin{array}{l}\text { Growth Control } \\
\text { (OD) }\end{array}$} \\
\hline & 256 & 128 & 64 & 32 & 16 & 8 & 4 & 2 & \\
\hline SA04 & 57 & 57 & 59 & 55 & 57 & 55 & 49 & 50 & 0.145 \\
\hline SA36 & 51 & 52 & 53 & 59 & 57 & 56 & 48 & 56 & 0.088 \\
\hline SA48 & 58 & 59 & 61.9 & 60 & 59 & 57 & 50 & 60 & 0.109 \\
\hline SA62 & 53 & 58 & 59.1 & 55 & 55 & 50 & 15 & 49 & 0.111 \\
\hline SA86 & 56 & 61 & 60 & 62 & 61 & 59 & 55 & 51 & 0.114 \\
\hline P value & 0.0003 & 0.0062 & 0.071 & 0.0079 & 0.0271 & 0.240 & 0.840 & 0.406 & \\
\hline
\end{tabular}

\section{Antibiofilm activities of quercetin}

Concerning the action of quercetin as antibiofilm, this molecule reduces biofilm formation against SA36 isolate of $S$. aureus at $32 \mu \mathrm{g} / \mathrm{mL}$, and the inhibition potency percent reached to 92 , and have a significant difference when compared to a positive control $(p=0.0041)$. Quercetin reduced biofilm formation at all concentrations against all five isolates except concentrations of $64 \mu \mathrm{g} / \mathrm{mL}$ against both SA36 and SA48 isolates. In particular, the lowest inhibited biofilm formation was 16\%, and the highest was $92 \%$ (Table 8). Significant differences was recorded at concentrations $256,8,4$, and $2 \mu \mathrm{g} / \mathrm{mL}$ when compared with positive control $(p=0.0221, p=0.02, p=0.0246, p=0.0369)$ respectively.

\section{Biofilm inhibitory activity of ascorbic acid}

Once the antibiofilm efficacy of ascorbic acid has been determined, we analyze their potential action against $S$. aureus biofilm formation. MTP assessed this ability, and these results showed complete inhibition of biofilm formation by ascorbate when compared to 
growth control (Table 8). The highest antibiofilm potency of ascorbic acid was $62 \%$ against SA86 isolate at concentration $32 \mu \mathrm{g} / \mathrm{mL}$, while the minimum power was recorded at concentration four $\mu \mathrm{g} / \mathrm{ml}$ a toward SA62 isolate. In spite of the low inhibition percent of biofilm formation, while there are a significant differences in the decreasing of biofilm formation at concentrations $256,128,32$, and $16 \mu \mathrm{g} / \mathrm{mL}(p=0.0003, p=0.0062$, $p=0.0079$, and $p=0.0271$ ) respectively when compared with OD of growth control.

\section{Discussion}

All $100 \mathrm{~S}$. aureus isolates were branded as Gram-positive; further cultural characteristics and biochemical test results were stated in Table 3. Out of these isolates, 91 isolates were coagulase-positive $S$. aureus, and nine were recorded as coagulasenegative. Results obtained from the conventional biochemical tests and PCR method match with a statistical confidence of $91 \%$ (The remaining $9 \%$ non-reluctant possibly due to analysis conditions and sample preparation) between the methods. This probably will be due to the concealing of the clumping factor by the capsular polysaccharides or due to misidentification of particular clumping factor producing CoNS; by this means, lessening its efficiency, reliability, and sensitivity (Subramanian et al., 2017). An additional test used $S$. aureus identification is the DNase test. All isolates of $S$. aureus have been positive for DNase activity in the present study. Parallel results have been reported previously with a lack of clarification; thus, additional tests are required for confirmation purposes.

In our study, $78 \mathrm{~S}$. aureus isolates showed the ability to hydrolyze gelatin, thus confirming the presence of the gelatinase enzyme. However, 81, 51, and 48 strains of $S$. aureus secrete protease, lipase enzymes, and nonwhite pigmented colonies, respectively. Among the 100 strains of $S$. aureus showed $\beta$-hemolytic, $\gamma$-hemolytic and $\alpha$-hemolytic properties, 71 strains of $S$. aureus showed the ability of $\beta$-hemolysin and only two isolates expressed $\alpha$-hemolysin, and 27 isolates demonstrated the $\gamma$-hemolytic activity. Likewise, hemolytic activity among 57 different clinical sources of $S$. aureus exhibited vigorous hemolytic activities and five clinical strains that had no ability of blood hydrolysis on blood agar (Tang et al., 2013). All isolates of S. aureus were undergone PCR assay using universally conserved $16 \mathrm{~S}$ rRNA and $n u c$ genes, specifically designed primers were used for discrimination of $S$. aureus isolates (Table 1), and all of the strains were positive for both genes (Fig. 3). Antimicrobial susceptibility carried out for 16 antimicrobials through disc diffusion methods, and the results are presented in Table 6 . The highly resistant percentage was seen against oxacillin $(99 \%)$ followed by penicillin $(97 \%)$, and the lowest resistant $1 \%$ recorded was against each of gentamycin, nitrofurantoin, and trimethoprim-sulfamethoxazole. Based on the antimicrobial susceptibility reports by Boada et al. (2018), among the 765 assessed $S$. aureus isolates, the maximum resistance rates were observed to a penicillin $(87.1 \%)$, followed by azithromycin (11.6\%), erythromycin $(11.2 \%)$ and clindamycin $(9.7 \%)$. Oxacillin and methicillin resistance mechanism is by gaining a gene that encodes a PBP2 homolog called PBP2a that is not susceptible to drug deed, and this is due to the serine residue that is not reachable by $\beta$-lactams at the active site of the TP of PBP2a (Foster, 2017).

Different results in both methods used for $\beta$-lactamase detection in all $S$. aureus isolates, the positive result in an iodometric method was $91 \%$, while 73 isolates could produce $\beta$-lactamase through Cefinase disk. Most strains of $S$. aureus were resistant to penicillin; nearly $20 \%$ of $S$. aureus remained susceptible to penicillin (Parija, 2014). 
Clinical S. aureus isolates were examined for biofilm formation via phenotypic and molecular assays, and any possible association between biofilm formation and bacterial genetic lineage was investigated. S. aureus remains the most recurrently encountered bacterial pathogen and is responsible for a variety of mild to life-threatening infections (El-Huneidi et al., 2006). The ability of $S$. aureus to adhesion and form biofilm makes them more resistant against antibiotics. Bacterial virulence factors such as adhesion play a vital role in catheter-related infections. Staphylococcus' ability to settle in artificial material is linked to two main mechanisms; polysaccharide slime production and host matrix protein adsorption on the biomaterial surface. When the biofilm is produced, it would be easy to run away from immune systems and to cause chronic infections. While PIA is essential for the formation of biofilm by $S$. aureus, in this study, we found in these isolates more than one gene of ica operon, i.e. icaADBC, cna, atl, fnbA and fnbB genes are associated with the production of biofilm in these isolates.

Although many genes and conditions are responsible for biofilm production, our results demonstrated that icaA, icaB, icaC, icaD, cna, atl, fnbA, and fnbB genes have a critical role in the production of biofilms. In this work we found that 89 out of 100 strains were biofilm producers developing almost black $(n=25)$, black $(n=15)$ or strong black colonies $(n=49)$ on CRA plate, while in MTP assay, all isolates produce biofilm with ranging from weak $(n=8)$, moderate $(n=71)$ and strong biofilm production $(n=21)$. Comparatively, similar results have been achieved elsewhere, stating that $50 \%$ of clinical S. aureus isolates to form a biofilm (Kouidhi et al., 2010). Out of 100 bacterial isolates, the formation of biofilm was recorded in $60 \%$ of isolates by CRA method, while PCR detection of biofilm-related genes, icaA, and icaD, revealed that both genes were present in $78 \%$ of the isolates (Salehzadeh et al., 2016). Discrepancies have been reported between phenotypic and genotypic methods for the detection of $S$. aureus producing biofilms (Yazdani et al., 2006). Statistical analysis revealed there is no significant difference between the biofilm formation using the MTP assay and the CRA method $(\mathrm{p}=0.8997)$. Numerous studies have confirmed that some $S$. aureus strains need icaADBC to form biofilms (Johnson et al., 2008). On the other hand, adhesion to host cells requires genes such as $f n b A, f n b B$, and $c n a$ that encode microbial surface constituents known as adhesive matrix molecules that are different from those involved in the adhesion on abiotic surfaces (Arciola et al., 2005).

In the present study, the prevalence of the icaC, icaD, and cna $(96 \%)$ and icaA, icaB, atl, fnbA, and genes were found to be $\% 80 \%, 72 \%, 80 \%$ and $86 \%$, respectively. This result may reflect the role of these genes in the pathogenicity of $S$. aureus isolates. However, $f n b B$ was found in a lower percentage $(60 \%)$. The prevalence of twelve genes involved in biofilm production explains that numerous factors may be useful in various stages of biofilm formation due to the ability of all the strains identified to form biofilm at different levels, but the gene incidence was different. Further research to clarify the expression of these genes in $S$. aureus strains should be considered (Nourbakhsh and Namvar, 2016), and they stated that the prevalence of the genes involved in biofilm production was: icaA (34.2\%), icaB (29.7\%), icaC (69.3\%), icaD (54.8\%), fnbA (38.1\%), fnbB $(46.6 \%)$, and can (18.3\%). Similar to our study, several other researchers have shown that the formation of slime and biofilm in $S$. aureus is associated with the presence of icaA and icaD genes (Cramton et al., 1999; Arciola et al., 2001; Vasudevan et al., 2003). Production of intercellular adhesion molecules, e.g., by icaABCD and other genes, plays an essential role in staphylococcal biofilm. Biofilm production may be the fundamental reason for the increasing antibiotic resistance of $S$. aureus strains. A 
significant association was observed between the presence of genes such as icaA, icaB, $i c a C$, icaD, can, atl, fnbA and $f n b B$, and biofilm formation. Although not all of the genes were found simultaneously in all the isolates of the biofilm producers, at least one of the related genes was detected in the entire isolates of the biofilm producers (except one strain). The ability to form biofilm in negative strains for one or more genes may be associated with some other genes associated with biofilm.

In the present study, the prevalence of the icaC, icaD, and cna $(96 \%)$ and icaA, icaB, atl, fnbA, and genes were found to be $\% 80 \%, 72 \%, 80 \%$ and $86 \%$, respectively. This result may reflect the role of these genes in the pathogenicity of $S$. aureus isolates. However, $f n b B$ was found in a lower percentage $(60 \%)$. The prevalence of twelve genes involved in production of biofilm explains that numerous factors may be useful in different steps of biofilm formation because all of the strains identified could form biofilm at various levels, but the incidence of genes was different. Further research should be considered to elucidate the expression of these genes in S. aureus strains. We investigated the effects of $Z$. officinale extract, quercetin, and ascorbic acid on biofilm formation using a static biofilm assay and using $S$. aureus as a model biofilm-forming microorganism, and found that quercetin inhibits the formation of biofilm when compared with $Z$. officinale extract and Ascorbic acid through the percentage of biofilm inhibition.

\section{Conclusion}

In the current study, a significant association between the presence of icaA, icaB, icaC, $i c a D, c a n, a t l, f n b A$, and $f n b B$ genes and biofilm formation were observed. Although all of the genes were not found in all of the biofilm producer isolates, however, in the entire biofilm producer isolates (except one isolate) at least one of the related genes was detected. The ability of biofilm formation in isolates negative for one or more genes might be related to some other biofilm-associated genes. The most critical future suggestions are to use all active components which present in the $Z$. officinale against biofilm formation in different bacterial species and genera.

Acknowledgments. This work supported by Salahaddin University-Erbil, Erbil, Iraq, as the Ph.D. program (No. 15738 on December 12, 2015). The authors would like to thank and grateful to Prof. Dr. Jawher F. Saeed for his support and technical assistance and Dr. Abdullah M.A. Qassab for his scientific evaluating.

\section{REFERENCES}

[1] Ali, B. H., Blunden, G., Tanira, M. O., Nemmar, A. (2008): Some phytochemical, pharmacological and toxicological properties of ginger (Zingiber officinale Roscoe): a review of recent research. - Food and Chemical Toxicology 46: 409-420.

[2] Alli, O. A., Ogbolu, D. O., Shittu, A. O., Okorie, A. N., Akinola, J. O., Daniel, J. B. (2015): Association of virulence genes with mecA gene in Staphylococcus aureus isolates from Tertiary Hospitals in Nigeria. - Indian Journal of Pathology and Microbiology 58: 464-71.

[3] Arciola, C. R., Baldassarri, L., Montanaro, L. (2001): Presence of icaA and icaD genes and slime production in a collection of Staphylococcal strains from catheter-associated infections. - Journal of clinical microbiology 39: 2151-2156.

[4] Arciola, C. R., Campoccia, D., Gamberini, S., Baldassarri, L., Montanaro, L. (2005): Prevalence of cna, fnbA and $f n b B$ adhesin genes among Staphylococcus aureus isolates 
from orthopedic infections associated to different types of implant. -FEMS Microbiol Lett. 246: 81-6.

[5] Balamurugan, P., Praveen Krishna, V., Bharath, D., Lavanya, R., Vairaprakash, P., Adline Princy, S. (2017): Staphylococcus aureus quorum regulator SarA targeted compound, 2 [(Methylamino) methyl] phenol inhibits biofilm and down-regulates virulence genes. Frontiers in Microbiology 8: 1290.

[6] Bayer, A. S., Abdelhady, W., Li, L., Gonzales, R., Xiong, Y. Q. (2016): Comparative efficacies of tedizolid phosphate, linezolid, and vancomycin in a murine model of subcutaneous catheter-related biofilm infection due to methicillin-susceptible and-resistant Staphylococcus aureus. - Antimicrobial agents and chemotherapy 60: 5092-5096.

[7] Benzie, I. F. F., Strain, J. J. (1996): The Ferric Reducing Ability of Plasma (FRAP) as a Measure of "Antioxidant Power": The FRAP Assay. - Analytical Biochemistry 239: 7076.

[8] Bimanand, L., Taherikalani, M., Jalilian, F. A., Sadeghifard, N., Ghafourian, S., Mahdavi, Z., Mohamadi, S., Sayehmiri, K., Hematian, A., Pakzad, I. (2018): Association between biofilm production, adhesion genes and drugs resistance in different SCCmec types of methicillin-resistant Staphylococcus aureus strains isolated from several major hospitals of Iran. - Iran J Bas Med Sci 21: 400.

[9] Blaiotta, G., Ercolini, D., Pennacchia, C., Fusco, V., Casaburi, A., Pepe, O., Villani, F. (2004): PCR detection of staphylococcal enterotoxin genes in Staphylococcus spp. strains isolated from meat and dairy products. Evidence for new variants of $s e G$ and seI in Staphylococcus aureus AB-8802. - J Appl Microbiol 97: 719-730.

[10] Boada, A., Pons-Vigués, M., Real, J., Grezner, E., Bolíbar, B., Llor, C. (2018): Previous antibiotic exposure and antibiotic resistance of commensal Staphylococcus aureus in Spanish primary care. - European Journal of General Practice 24: 125-130.

[11] Cheung, A. L., Bayer, A. S., Zhang, G., Gresham, H., Xiong, Y.-Q. (2004): Regulation of virulence determinants in vitro and in vivo in Staphylococcus aureus. - FEMS Immunology \& Medical Microbiology 40: 1-9.

[12] CLSI (2017). Performance Standards for Antimicrobial Susceptibility Testing. - Clinical and Laboratory Standards Institute, M100.

[13] Cramton, S. E., Gerke, C., Schnell, N. F., Nichols, W. W., Götz, F. (1999): The intercellular adhesion (ica) locus is present in Staphylococcus aureus and is required for biofilm formation. - Infection and Immunity 67: 5427-5433.

[14] El-Huneidi, W., Bdour, S., Mahasneh, A. (2006): Detection of enterotoxin genes seg, seh, $s e i$, and $s e j$ and of a novel aroA genotype in Jordanian clinical isolates of Staphylococcus aureus. - Diagn Microbiol Infect Dis 56: 127-132.

[15] Fey, P., Said-Salim, B., Rupp, M., Hinrichs, S., Boxrud, D., Davis, C., Kreiswirth, B., Schlievert, P. (2003): Comparative molecular analysis of community-or hospital-acquired methicillin-resistant Staphylococcus aureus. - Antimicrobial agents and chemotherapy 47: 196-203.

[16] Foster, T. J. (2005): Immune evasion by staphylococci. - Nature reviews microbiology 3: 948.

[17] Foster, T. J. (2017): Antibiotic resistance in Staphylococcus aureus: Current status and future prospects. - Fems microbiology reviews 41: 430-449.

[18] Gowrishankar, S., Kamaladevi, A., Balamurugan, K., Pandian, S. K. (2016): In vitro and in vivo biofilm characterization of methicillin-resistant Staphylococcus aureus from patients associated with pharyngitis infection. - BioMed research international 16: 1-16.

[19] Habib, S. H. M., Makpol, S., Hamid, N. A. A., Das, S., Ngah, W. Z. W., Yusof, Y. A. M. (2008): Ginger extract (Zingiber officinale) has anti-cancer and anti-inflammatory effects on ethionine-induced hepatoma rats. - Clinics 63: 807-813.

[20] Helgadóttir, S., Pandit, S., Mokkapati, V. R., Westerlund, F., Apell, P., Mijakovic, I. (2017): Vitamin C pretreatment enhances the antibacterial effect of cold atmospheric plasma. - Frontiers in cellular and infection microbiology 7: 43. 
[21] Hirai, I., Okuno, M., Katsuma, R., Arita, N., Tachibana, M., Yamamoto, Y. (2010): Characterisation of anti-Staphylococcus aureus activity of quercetin. - International Journal of Food Science and Technology 45: 1250-1254.

[22] Jeong, S., Kim, H. J., Ha, N.-C., Kwon, A.-R. (2019): Crystal Structure of SAV0927 and Its Functional Implications. - Journal of microbiology and biotechnology 29: 500-505.

[23] Johnson, M., Cockayne, A., Morrissey, J. A. (2008): Iron-regulated biofilm formation in Staphylococcus aureus Newman requires ica and the secreted protein Emp. - Infect Immun 76: 1756-1765.

[24] Karasu, S. T., Rathish, K. C. (2014): Evaluation of Direct Tube Coagulase Test in Diagnosing Staphylococcal Bacteremia. - Journal of Clinical and Diagnostic Research 8: DC19-DC21.

[25] Khoramrooz, S. S., Mansouri, F., Marashifard, M., Malek Hosseini, S. A., Akbarian, C. F., Ganavehei, B., Gharibpour, F., Shahbazi, A., Mirzaii, M., Darban-Sarokhalil, D. (2016): Detection of biofilm related genes, classical enterotoxin genes and agr typing among Staphylococcus aureus isolated from bovine with subclinical mastitis in southwest of Iran. - Microb Pathog 97: 45-51.

[26] Kiedrowski, M. R., Horswill, A. R. (2011): New approaches for treating staphylococcal biofilm infections. - Annals of the New York Academy of Sciences 1241: 104-121.

[27] Kim, H.-S., Park, H.-D. (2013): Ginger extract inhibits biofilm formation by Pseudomonas aeruginosa PA14. - PloS one 8: e76106.

[28] Kouidhi, B., Zmantar, T., Hentati, H., Bakhrouf, A. (2010): Cell surface hydrophobicity, biofilm formation, adhesives properties and molecular detection of adhesins genes in Staphylococcus aureus associated to dental caries. - Microbial pathogenesis 49: 14-22.

[29] Mcfarland, J. (1907): Nephelometer: an instrument for media used for estimating the number of bacteria in suspensions used for calculating the opsonic index and for vaccines. - Journal of American Medical Association 14: 1176-1178.

[30] Nair, S., Desai, S., Poonacha, N., Vipra, A., Sharma, U. (2016): Antibiofilm Activity and Synergistic Inhibition of Staphylococcus aureus Biofilms by Bactericidal Protein P128 in Combination with Antibiotics. - Antimicrob Agents Chemother 60: 7280-7289.

[31] Nourbakhsh, F., Namvar, A. E. (2016): Detection of genes involved in biofilm formation in Staphylococcus aureus isolates. - GMS hygiene and infection control 11: 1-11.

[32] Onsare, J. G., Arora, D. S. (2015): Antibiofilm potential of flavonoids extracted from Moringa oleifera seed coat against Staphylococcus aureus, Pseudomonas aeruginosa and Candida albicans. - J Appl Microbiol 118: 313-25.

[33] Pandit, S., Ravikumar, V., Abdel-Haleem, A. M., Derouiche, A., Mokkapati, V. R. S. S., Sihlbom, C., Mineta, K., Gojobori, T., Gao, X., Westerlund, F., Mijakovic, I. (2017): Low Concentrations of Vitamin C Reduce the Synthesis of Extracellular Polymers and Destabilize Bacterial Biofilms. - Frontiers in Microbiology 8.

[34] Parija, S. C. (2014): Textbook of Microbiology and Immunology. - India, Elsevier Health Sciences.

[35] Phuong, N. T. M., Van Quang, N., Mai, T. T., Anh, N. V., Kuhakarn, C., Reutrakul, V., Bolhuis, A. (2017): Antibiofilm activity of alpha-mangostin extracted from Garcinia mangostana L. against Staphylococcus aureus. - Asian Pac J Trop Med 10: 1154-1160.

[36] Rodrigues, A., Gomes, A., Marcal, P. H., Dias-Souza, M. V. (2017): Dexamethasone abrogates the antimicrobial and antibiofilm activities of different drugs against clinical isolates of Staphylococcus aureus and Pseudomonas aeruginosa. - J Adv Res 8: 55-61.

[37] Roy, R., Tiwari, M., Donelli, G., Tiwari, V. (2018): Strategies for combating bacterial biofilms: A focus on anti-biofilm agents and their mechanisms of action. - Virulence 9: 522-554.

[38] Salehzadeh, A., Zamani, H., Langeroudi, M. K., Mirzaie, A. (2016): Molecular typing of nosocomial Staphylococcus aureus strains associated to biofilm based on the coagulase and protein A gene polymorphisms. - Iranian journal of basic medical sciences 19: 1325. 
[39] Saraiva, A. M., Saraiva, C. L., Gonçalves, A. M., Soares, R. R., Mendes, F. D. O., Cordeiro, R. P., Xavier, H. S., Pisciottano, M. N. C. (2012): Antimicrobial activity and bioautographic study of antistaphylococcal components from Caesalpinia pyramidalis Tull. - Brazilian Journal of Pharmaceutical Sciences 48: 147-154.

[40] Sérgio, D. D. C. J., João, V. D. O. S., Luís, A. D., Almeida, C., Marcela, A. P., Nereide, S. S. M., Cavalcanti, I. M. F. (2018): Antibacterial and antibiofilm activities of quercetin against clinical isolates of Staphyloccocus aureus and Staphylococcus saprophyticus with resistance profile. - International Journal of Environment, Agriculture and Biotechnology 3: 1948-1958.

[41] Shahmoradi, M., Faridifar, P., Shapouri, R., Mousavi, S. F., Ezzedin, M., Mirzaei, B. (2019): Determining the Biofilm Forming Gene Profile of Staphylococcus aureus Clinical Isolates via Multiplex Colony PCR Method. - Reports of Biochemistry and Molecular Biology 7: 181.

[42] Shin, H. J., Lee, H.-S., Lee, D.-S. (2010): The synergistic antibacterial activity of 1-acetylbeta-carboline and beta-lactams against methicillin-resistant Staphylococcus aureus (MRSA). - Journal of microbiology and biotechnology 20: 501-505.

[43] Singh, A., Ahmed, A., Prasad, K. N., Khanduja, S., Singh, S. K., Srivastava, J. K., Gajbhiye, N. S. (2015): Antibiofilm and membrane-damaging potential of cuprous oxide nanoparticles against Staphylococcus aureus with reduced susceptibility to vancomycin. Antimicrob Agents Chemother 59: 6882-90.

[44] Stoilova, I., Krastanov, A., Stoyanova, A., Denev, P., Gargova, S. (2007): Antioxidant activity of a ginger extract Zingiber officinale. - Food chemistry 102: 764-770.

[45] Subramanian, A., Chitalia, V. K., Bangera, K., Vaidya, S. P., Warke, R., Chowdhary, A., Deshmukh, R. A. (2017): Evaluation of HiaureusTM Coagulase Confirmation Kit in Identification of Staphylococcus aureus. - Journal of clinical and diagnostic research 11: DC08-DC13.

[46] Szczuka, E., Urbańska, K., Pietryka, M., Kaznowski, A. (2013): Biofilm density and detection of biofilm-producing genes in methicillin-resistant Staphylococcus aureus strains. - Folia microbiologica 58: 47-52.

[47] Tang, J., Tang, C., Chen, J., Du, Y., Yang, X. N., Wang, C., Zhang, H., Yue, H. (2011): Phenotypic characterization and prevalence of enterotoxin genes in Staphylococcus aureus isolates from outbreaks of illness in Chengdu City. - Foodborne Pathogenic Diseases 8: 1317-20.

[48] Tang, J., Chen, J., Li, H., Zeng, P., Li, J. (2013): Characterization of adhesin genes, staphylococcal nuclease, hemolysis, and biofilm formation among Staphylococcus aureus strains isolated from different sources. - Foodborne pathogens and disease 10: 757-763.

[49] Trübe, P., Hertlein, T., Mrochen, D. M., Schulz, D., Jorde, I., Krause, B., Zeun, J., Fischer, S., Wolf, S. A., Walther, B. (2019): Bringing together what belongs together: Optimizing murine infection models by using mouse-adapted Staphylococcus aureus strains. International Journal of Medical Microbiology 309: 26-38.

[50] Vasudevan, P., Nair, M. K. M., Annamalai, T., Venkitanarayanan, K. S. (2003): Phenotypic and genotypic characterization of bovine mastitis isolates of Staphylococcus aureus for biofilm formation. - Veterinary microbiology 92: 179-185.

[51] Wang, J., Nong, X.-H., Zhang, X.-Y., Xu, X.-Y., Amin, M., Qi, S.-H. (2017): Screening of anti-biofilm compounds from marine-derived fungi and the effects of secalonic acid D on Staphylococcus aureus biofilm. - Journal of Microbiology and Biotechnology 27: 10781089.

[52] Yazdani, R., Oshaghi, M., Havayi, A., Pishva, E., Salehi, R., Sadeghizadeh, M., Foroohesh, H. (2006): Detection of icaAD gene and biofilm formation in Staphylococcus aureus isolates from wound infections. - Iran J Publ Health 35(2): 25-28.

[53] Yousefi, M., Pourmand, M. R., Fallah, F., Hashemi, A., Mashhadi, R., Nazari-Alam, A. (2016): Characterization of Staphylococcus aureus biofilm formation in urinary tract infection. - Iranian journal of public health 45(4): 485-493. 